\title{
Evaluation of Four Commercial Varieties of Tobacco $^{1}$
}

\author{
C. L. González-Molina, A. Acosta-Matienzo, and Elvin G. Boneta-Garcia
}

\section{INTRODUCTION}

Filler-type tobacco has been grown in Puerto Rico for a long time. At present it ranks as the third agricultural enterprise of the Island. Approximately 26,000 cuerdas ( 0.9712 acre) are planted annually with total yields of about 281,000 hundredweights and an average yield per acre of 10.8 hundredweights. With these low yields tobacco cannot possibly be a highly profitable crop. Low-yielding varieties grown commercially are, in part, responsible for this situation. The poor steep soils where tobacco is grown and the undesirable techniques used by farmers also play an important role.

At present, the commercial varieties grown in the Island have been introduced from foreign countries or obtained by farmers from open-pollinated strains. As most tobacco growers are not familiar with techniques for seed selection required to keep pure stocks, in all possibility strains developed in this way are not genetically pure.

This paper reports the results of a variety trial where the leading commercial variety, V.12, was compared with other two standard varieties, and with a new promising tobacco selection.

\section{VARIETIES}

The most important varieties grown in the Island are V.12, C.10, Olor, and Selección Olor. V.12 is the oldest variety still grown. Once it was the most popular variety, but during the past 3 or 4 years it has been reduced to small areas of the Tobacco Region. It is a tall variety producing about 32 or 34 leaves of acceptable size, of very good quality, with moderate black shank resistance, but susceptible to common mosaic.

The Olor was introduced from the Dominican Republic many years ago. It is a short plant with wide leaves, about 24 to 26 long, of a good curing and fermenting quality, black shank-resistant, but susceptible to mosaic.

C.10 is of unknown origin, but was probably obtained from seed of a segregating strain from the old Tobacco Institute Farm at Caguas. Al-

1 Contribution from the Gurabo Substation.

2 Assistant Plant Breeder, Assistant Horticulturist, and Research Assistant in Agronomy, respectively, Agricultural Experiment Station, University of Puerto Rico, Gurabo, P.R. Appreciation is expressed to Assistant Director M. A. LugoLopez for his useful suggestions and advices. 
though the Experiment Station does not recommend this variety, many farmers prefer it because of its high yield in some districts. It has acceptable curing and fermenting qualities and a moderate resistance to black shank, but is susceptible to mosaic. Fields planted to this variety are not uniform. Differences in plant type and size and in leaf size and shape are generally observed. Probably, this results from genetic segregations still underway.

Selección Olor was developed at the Gurabo Substation by selfing and selection of superior types of the Olor variety. It is a tall plant producing about 46 to 48 leaves of medium size. It is very resistant to black shank but susceptible to mosaic, and of acceptable curing and fermenting quality. Other varieties are grown but are of minor economic importance. Since formal research has never been conducted to evaluate yield and grading of these commercial varieties, a varietal test was established at the Gurabo Substation to study their behavior in this particular area. It is well known that varietal response can be modified by environmental conditions including soils, weather, and other factors.

\section{MATERIALS AND METHODS}

The experimental area was located on an alluvial soil at the Gurabo Substation. A double latin-square design was used with four treatments repeated in each square. Seed were sown in clay pots filled with a soil mixture of 1 part loam to 1 part filter-press cake. The soil was sterilized with methylbromide at the rate of 2 pounds per 100 square feet. After 3 to 4 weeks seedlings were transferred to vitabands on flats of sterilized soil and 3 to 4 weeks later they were planted on the field with $31 / 2$ feet between rows and $11 / 2$ feet between plants. Experimental plots were 20 feet long and 18 feet wide with 5 rows of 12 plants each, that is, 60 plants per plot. A 6-8-10 fertilizer was applied in split portions in the holes at planting time at a rate of 15 hundredweights per acre. Cultural practices and insect control followed Station recommendations. Plants were topped as soon as the inflorescence emerged. Suckering was practiced when needed. Tobacco leaves were primed every week and cured in conventional curing sheds. Data about black shank resistance were recorded, as a difference in disease resistance among the varieties tested was evident. Cured tobacco was weighed and classified according to USDA standards and data were recorded.

\section{RESULTS AND DISCUSSION}

Table 1 gives the total weight and the cash value of cured tobacco per acre for each variety. It includes also data about black shank resistance. The cash value of the crop was based on the scale of prices received by 
farmers during the year 1959 for the different USDA grades of tobacco. As can be observed, Selección Olor produced 1,843 pounds per cuerda, the highest yield. Olor, C.10, and V.12 ranked in second, third, and fourth places, respectively. Selección Olor also produced the highest cash value among the four varieties and the best black shank resistance. It is obvious that black shank susceptibility was a limiting factor in the total yield, adversely affecting susceptible varieties. The difference in yields of cured tobacco between the Selección Olor and Olor, was not significant at the 1-percent level, but Selección Olor was highly significant over C.10 and V.12, and Olor over V.12. No difference at the 1-percent level was observed between C.10 and V.12. At a 5-percent level, however, the difference in yield of C.10 was significant over V.12. Table 2 summarizes the analysis of variance of the data obtained.

TABLE 1.-Weight in pounds of cured tobacco, cash value, and percentage of black shank resistance of the 4 commercial varieties compared

\begin{tabular}{|c|c|c|c|}
\hline Variety & $\begin{array}{l}\text { Mean weight per } \\
\text { cuerda' of cured } \\
\text { tobacco }\end{array}$ & $\begin{array}{l}\text { Mean cash value } \\
\text { per calerda' of } \\
\text { classified tobacco }\end{array}$ & $\begin{array}{l}\text { Black shank } \\
\text { resistance }\end{array}$ \\
\hline & Pounds & Dollars & Percent \\
\hline Selección Olor & 1,843 & 555 & 99.78 \\
\hline Olor & 1,600 & 507 & 95.75 \\
\hline C.10 & 1,335 & 407 & 84.97 \\
\hline V.12 & 949 & 261 & 55.34 \\
\hline Standard deviations of the means ${ }^{2}$ & 0.730 & 0.289 & 0.014 \\
\hline
\end{tabular}

${ }^{1} \mathrm{~A}$ cuerda is the equivalent of 0.9712 acre.

2 Degrees of freedom for error $=12$.

Table 3 indicates that, at the 1-percent level, the difference in cash value of Selección Olor was highly significant over Olor, C.10, and V.12, and also the eash value of Olor was highly significant over C.10 and V.12; C.10 was highly significant over V.12.

Data on black shank resistance were recorded and analyzed (see table 1). Selección Olor and Olor were the more resistant varieties with 99.78 and 95.75 percent, respectively, while V.12 was the most susceptible with only a 55.3-percent resistance. Differences in resistance of both Selección Olor and Olor were highly significant over C.10 and V.12 (see table 4).

V.12 once was very resistant to black shank, but it has been losing this resistance, possibly because of the poor techniques used in seed selection. In general, proper seed-selection techniques should be used in order to maintain resistance to this disease. 
TABLE 2.-Summary of the analysis of variance of cured-lobacco yield obtained from \& commercial tobacco varieties tested

\begin{tabular}{l|r|r|r|r|r|r}
\hline \multicolumn{1}{c|}{ Source } & $\begin{array}{r}\text { Degrees } \\
\text { of } \\
\text { of }\end{array}$ & Sum of squares & Mean squares & $F$ & $F .05$ & \multirow{2}{*}{$F_{.01}$} \\
\hline Total & 31 & 327.970 & & & & \\
Rows & 6 & 20.558 & 3.426 & & & \\
Columns & 6 & 9.547 & 1.590 & & & \\
Squares & 1 & .353 & .353 & & & \\
Treatments & 3 & 242.411 & 80.801 & $18.949^{2}$ & 3.49 & 5.95 \\
Treatments x squares & 3 & 3.935 & 1.312 & & & \\
Error & 12 & 51.166 & 4.264 & & & \\
\hline
\end{tabular}

${ }^{1}$ Significant at the 1-percent level.

TABLE 3.-Summary of the analysis of variance of the cash value of yields obtained from \& commercial tobacco varieties under comparison

\begin{tabular}{l|r|r|r|r|r|r}
\hline \multicolumn{1}{c|}{ Source } & $\begin{array}{r}\text { Degrees } \\
\text { of } \\
\text { freedom }\end{array}$ & Sum of squares & Mean squares & $F$ & $F .09$ & $F .01$ \\
\hline Total & 31 & 41.402 & & & & \\
Rows & 6 & 1.376 & 0.293 & & & \\
Columns & 6 & 2.424 & .404 & & & \\
Squares & 1 & 1.030 & 1.030 & & & \\
Treatments & 3 & 27.891 & 9.297 & $13.876^{1}$ & 3.49 & 5.95 \\
Treatments x squares & 3 & .645 & .215 & & & \\
Error & 12 & 8.036 & .670 & & & \\
\hline
\end{tabular}

1 Significant at the 1-percent level.

TABLE 4.-Summary of the analysis of variance of the percentage of black shank resistance exhibited by 4 commercial varities under comparison

\begin{tabular}{l|r|r|r|r|r|r}
\hline \multicolumn{1}{c|}{ Source } & $\begin{array}{r}\text { Degrees } \\
\text { of } \\
\text { freedom }\end{array}$ & Sum of squares & Mean squares & $F$ & $F .06$ & $F_{.01}$ \\
\hline Total & 31 & 1.038 & & & & \\
Rows & 6 & .020 & 0.003 & & & \\
Columns & 6 & .024 & .006 & & & \\
Squares & 1 & .001 & .001 & & & \\
Treatments & 3 & .969 & .323 & $201.875^{1}$ & 3.49 & 5.95 \\
Treatments x squares & 3 & .005 & .001 & & & \\
Error & 12 & .019 & .0016 & & & \\
\hline
\end{tabular}

${ }^{1}$ Significant at the 1-percent level.

Overall resuts indicate that both Selección Olor and Olor are superior varieties to V.12 and C.10, considering yields, crop cash value, and resistance to black shank. The use of these superior varieties will lead to increased farm income. 


\section{SUMMARY}

This paper reports data from an experiment including four commercial tobacco varieties which was conducted at the Gurabo Substation. Selección Olor and Olor produced higher yields of cured tobacco than the other two varieties under comparison, namely, C.10 and V.12. Selección Olor produced tobacco of superior grading with a higher cash value, followed by Olor. Both Selección Olor and Olor exhibited higher resistance to black shank. Yields and black shank resistance of the well-known variety V.12 were lower than the others. From a practical standpoint Selección Olor and Olor are more profitable varieties than the others.

\section{RESUMEN}

Los datos obtenidos de un experimento de campo en los terrenos de la Subestación Experimental Agrícola de Gurabo demuestran que las variedades Selección Olor y Olor produjeron rendimientos, a base de tabaco curado, superiores a los producidos por las variedades C.10 y V.12. La Selección Olor fué superior a las otras variedades cuando éstas se evaluaron a base de la clasificación y del valor de la cosecha. La variedad Olor fué segunda en orden de importancia. La variedad V.12 no sólo fué la que produjo rendimientos inferiores, sino que también tuvo la mayor infección de la enfermedad conocida como pata prieta. Los datos indican que a los agricultores les conviene más sembrar las variedades Selección Olor y Olor que las C.10 y V.12. 